Article

\title{
Analysis of Hospitality, Leisure, and Tourism Studies in Chile
}

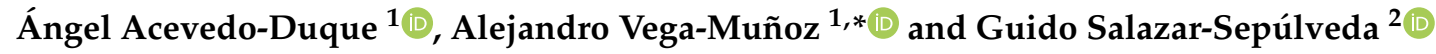 \\ 1 Facultad de Administración y Negocios, Universidad Autónoma de Chile, Santiago 7500912, Chile; \\ angel.acevedo@uautonoma.cl \\ 2 Departamento de Ingeniería Industrial—Facultad de Ingeniería, Universidad Católica de la Santísima \\ Concepción, Concepción 4090541, Chile; gsalazar@ucsc.cl \\ * Correspondence: alejandro.vega@uautonoma.cl
}

Received: 30 July 2020; Accepted: 1 September 2020; Published: 4 September 2020

check for updates

\begin{abstract}
This article provides a scientific production overview of hospitality, leisure, and tourism studies in Chile, including key factors of interest regarding this social science subdiscipline. The fundamental knowledge contributions are examined using a scientometric approach (spatial, productive, of impact, and relational) based on data from records stored in the Web of Science (JCR and ESCI). This approach aims to critically analyze the scientific production on hospitality, leisure, and tourism (HLT) with contributions from authors affiliated with Chile, to respond to the connection between this research, the sectoral education, and sustainable development of the HLT industry. At the results level, an increase in scientific production in the last decade, a breadth revealed in publications' quality terms, insertion in worldwide relevance co-authorship networks, an evolution from general issues to those of the discipline itself (cultural tourism, wine tourism, tourism marketing, hospitality industry, and sustainable tourism), a concentration on ecotourism education, and a disconnection between the diverse knowledge-producing centers and those of sectoral training were identified.
\end{abstract}

Keywords: scientometrics; hospitality; leisure; tourism; sustainable; Chile

\section{Introduction}

The interest of this study focuses on studies conducted regarding the hospitality, leisure, and tourism industry, centered in sustainability. Its set of activities has become a growing economic sector that can be found within the social sciences subdisciplines, which is transforming its market processes, thus, directly or indirectly generating new tourism services [1]. This social phenomenon is currently regarded as one of the greatest commercial seductions in modern times and an important part of our consumer society [2]. This includes commercial, leisure, pleasure, enjoyment, professional goals, and other activities related to people spending time outside of their habitual residences.

Thereby, this article's objective is to critically analyze the scientific production on hospitality, leisure, and tourism (HLT) — which has counted on contributions made by Chilean-affiliated authors-taking into account global references concerning this field which are increasingly identified and highlighted in order to manage the pre-existing knowledge and promote a connection between research and improvement of the current understanding of this sustainable industry [3,4]. Thus, based on articles published in Web of Science (WoS) journals, the present work conducted an exploration of 167 articles of Chilean affiliation (2nd South American country in knowledge production in HLT) to identify the thematic areas on which the current debate regarding sustainable tourism revolves. (The five largest contributors to the accumulation of world knowledge in this subdiscipline between 2010 and 2019 were the USA (26\% contribution to global co-authorship), the United Kingdom (12\%), 
Australia (10\%), China (9\%), and Spain (8\%).) This research seeks to give an answer regarding the relationship between the sustainability and the nascent Chilean research in hospitality, leisure, and tourism, and discover the contribution of this research to higher education at the service of this "industry without chimney".

In this way, this article explores interest areas regarding tourism and scientific articles that address this discipline, taking into account all its contexts, in particular sustainability, due to the importance that hospitality, leisure, and tourism has acquired in the academic research world of sustainability $[5,6]$. This is reflected, in a broad sense, by the increasing attention that this subdiscipline has received from high impact speeches, studies, and works conducted during the last few years [7], both in journals exclusively dedicated to this activity and other scientific areas that analyze this tourism enterprise [8]. Furthermore, due to its increasing scientific, economic, and social influence, this activity causes further interest in researchers, pushing them to continue exploring and creating knowledge [9].

\section{Background}

\subsection{The Reinvention of Hospitality, Leisure, and Tourism in the World and Its Impact on Businesses}

When a third-world country utilizes tourism as a development strategy, it ends up immersed in a global system over which it barely has control [10]. Since the international tourism industry is a product of the metropolises' capitalist initiatives [11], the better business techniques, greater resources, and commercial powers of metropolitan companies allow them to control many of the third-world touristic destinations. Within the tourism sector, business tourism stands out, which is seen as an emergent subsector, although some countries already consider it to be in a mature stage.

Due to this reason, the global perspectives of the twenty-first century propose that public, private, and social-nature organizations should adopt innovative strategies from this discipline in accordance with the environment's challenging demands [12]. For this reason, traditional businesses give up their space to incorporate mechanisms that answer to the business world needs in order to turn into intelligent, proactive, dynamic, creative, and decentralized institutions where the management of natural resources, space, and enjoyment stand as a fundamental piece to achieve the tourism goals [13].

Szmulewicz-Espinosa [14] already identified tourism as one of the most important economic activities for many countries, highlighting its focus on businesses that offer a wide range of possibilities to the people immersed in this subdiscipline as its main characteristic. In accordance with the United Nations World Tourism Organization (UNWTO) [15], the period between 2018 and 2019 marked the ninth and tenth consecutive years of international tourism's persistent growth. A total of 1.4 billion tourists traveled around the world between 2018 and 2019; therefore, tourism generated US \$1.7 trillion worth of world exports in 2018.

The UNWTO barometer [16] — which includes a Confidence Index based on the Expert Panel survey that provides an evaluation of recent performance and short-term prospects for international tourism - shows that the arrival of international tourists (overnight visitors) grew by $4 \%$ in January 2020 compared to the same period in the prior year. The growth results were led by Africa $(+4 \%)$ and the Middle East $(+8 \%)$, followed by Asia and the Pacific $(+5 \%)$. Europe $(+6 \%)$ and the Americas $(+2 \%)$ had a more moderate growth during the first half of 2019 (Figure 1$)$.

As for subregions, the Caribbean $(+11 \%)$ registered the highest growth, followed by North Africa $(+9 \%)$, and South Asia and Northeast Asia ( $+7 \%$ both). Confidence in global tourism performance is still positive but cautious and with signs of moderate growth during the rest of the year according to the last UNWTO Confidence Index.

The specialists from this entity analyzed that, throughout 2019, 1.5 billion international tourist arrivals were registered worldwide [15]. It is expected that this $4 \%$ growth with respect to the previous year repeats for the rest of 2020, which confirms tourism's position as a thriving and resistant economic sector, especially when taking the current uncertainties into account. However, the first UNWTO projections for 2020 suggest that international arrivals could decrease by $20-30 \%$ relative to 2019 [17,18]. 
Viewing Figure 2, it is possible to notice the growth experienced by production through this century, which has led it to stand-in line with its weight regarding world tourism-as one of the leading research disciplines in the global economy, although it's still far from other fields' hegemony [3].

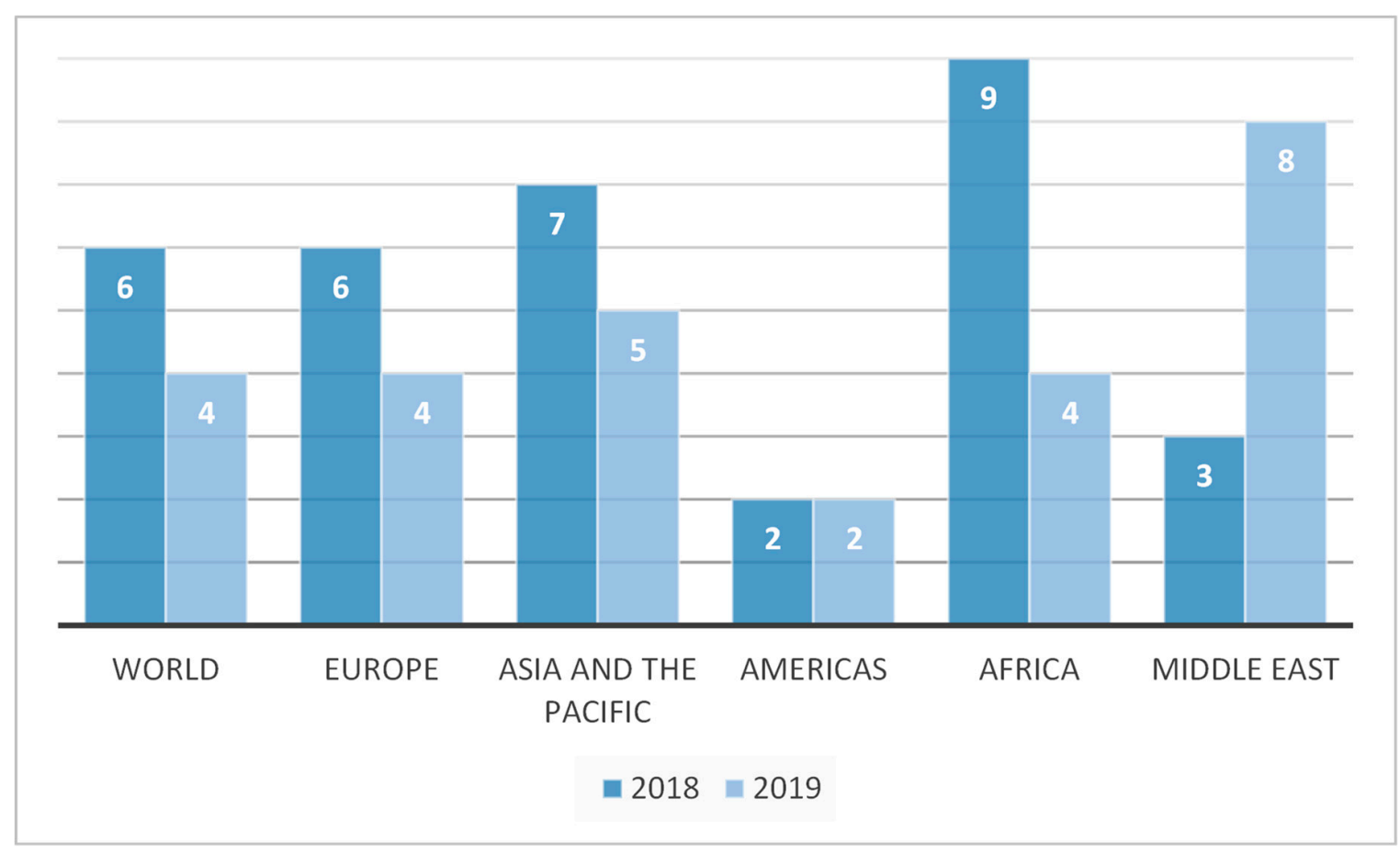

Figure 1. International tourist arrivals (\% change).

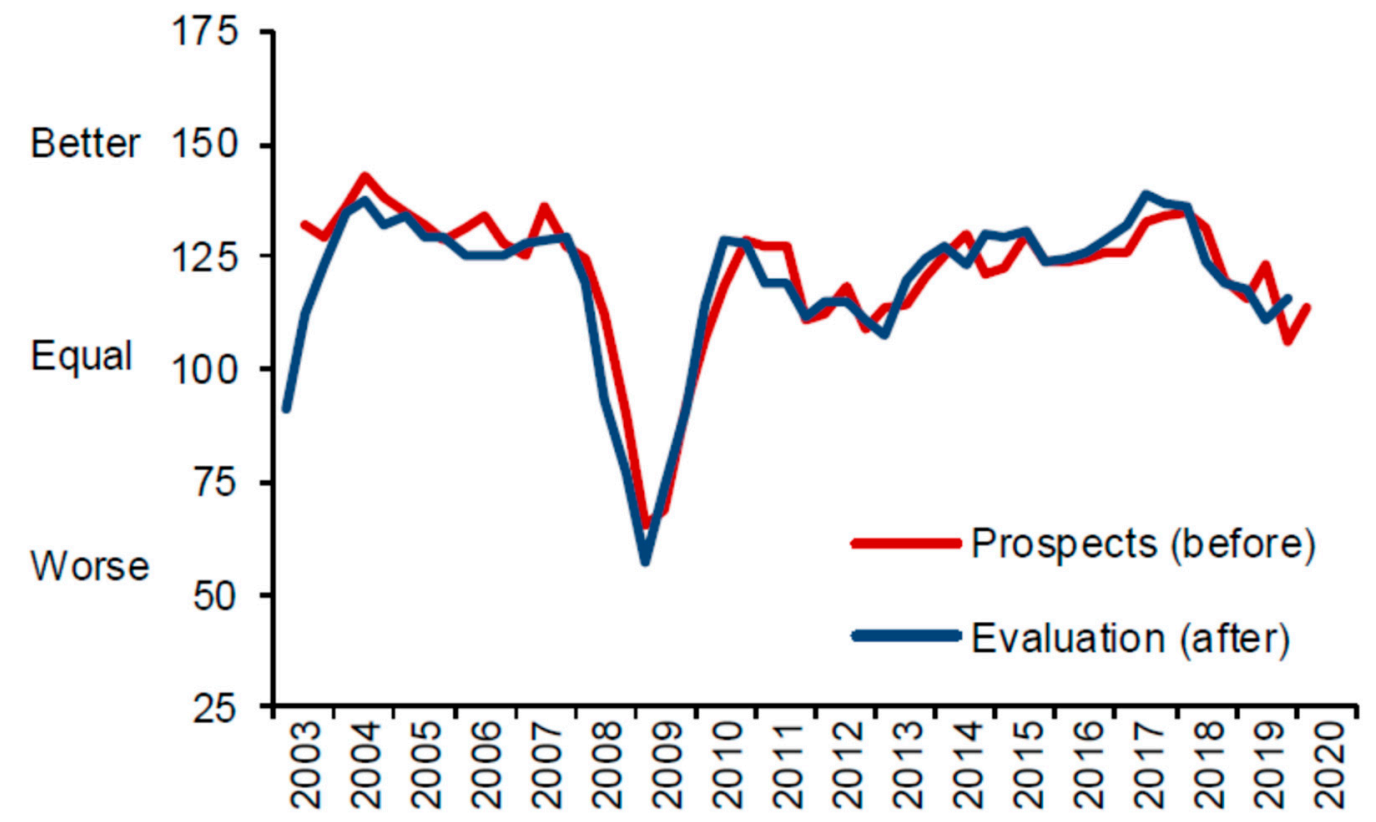

Figure 2. United Nations World Tourism Organization (UNWTO) Confidence Index: world.

Precisely for this reason, it is necessary to manage growth with responsibility and make the best of the opportunities that tourism offers to communities around the world. Until now, growth has been fueled by a strong economy, affordable air travel, increased air connectivity, and facilitation of visas at the beginning of this year. However, weaker economic indicators, prolonged uncertainty due to Brexit, 
commercial and technological tension, growing geopolitical challenges, and pandemic uncertainty have begun to affect businesses and consumers.

\subsection{Knowledge Management in Hospitality, Leisure, and Tourism in Chile}

Knowledge globalization and intellectual capital growth have generated interest in the education sector, particularly concerning higher education institutions [19]; thereby, these trends are imposed at highly competitive levels within this economic sector [20]. At universities, a gap persists in regard to the roles that the knowledge community and its management should demand from these houses of study in terms of quality and excellence. To Rodríguez-Ponce [21], universities and educational centers are very diverse and only a small amount of them perform the required tasks efficiently.

These houses of study can improve their productivity and competitiveness levels by identifying and taking advantage of the knowledge that exists within them, which makes them part of the knowledge management function [22,23]. In the university field, approaching knowledge management has become a focus of interest and importance for scientific settings worldwide [24], focusing on academic publications, conferences, research meetings, and websites, among others. In this sense, it constitutes a novel and complex research field whose gestation started in the early 1980s and 1990s in countries such as Sweden and the United States [25]. In this regard and in accordance with what has been stated by the previously mentioned authors, it is important to point out that, since then, research and scholarship regarding tourism have been amplified, involving a growing increase in scientific journals and new doctors in the late 20th century [26-28].

Thus, according to Benckendorff and Zehrer [29] in the early 1990s, some researchers argued that tourism was established as a scientific discipline, and while others only partially supported this argument, many academics still rejected it. Therefore, its application represents a frame of reference for the academic world where leaders from different sectors get involved in projects attempting to capture and create new knowledge in this field, thus, increasing their collaborators' learning [30].

In recent times, the use of terms such as knowledge management and organizational learning in hospitality, leisure, and tourism management has gained ground within work processes [31]. Academics have been investigating the epistemology, knowledge domain, and/or intellectual structure of these disciplines to elucidate how they have evolved over time. Since many disciplines have reached a significant maturity level regarding the tourism world [32], there has been a significant interest in evaluating and monitoring the disciplines' evolution based on topics that are not only of interest to the nation, but to everyone who promotes knowledge and science.

While what has been commented by the authors and the current importance of this research regarding the referred topics is true, the interest concerning including hospitality, leisure, and tourism into the diverse sectors of national and international economies becomes clear [33]. Therefore, associating with academic work processes such as information technology, communication, management consulting, and the information world, in general, becomes essential. For this reason, to Jain, Sahney, and Sinha [34], these particularities directly allude to labeling this type of company as knowledge-creating organizations and service providers par excellence. Given this situational context, it should be noted that acknowledging hospitality, leisure, and tourism as an applied field is commonly accepted. That being said, many academics may strive to suggest new approaches and methods to the professionals instead of the researchers [32]. However, in order to promote this field, researchers need to know the progress and evolution as such and implement them to modern teaching, which refers to the idea of transmitting knowledge and training creative and innovative people to be able to enhance their ideas by utilizing various learning and teaching means and strategies [35] and using knowledge management to generate intellectual capital excellence.

In Chile, 137 centers currently offer higher education. These are classified into 41 technical training centers (technical and technological training), 35 professional institutes (education for work), 6 armed forces institutes, and 55 universities that offer undergraduate programs and, in the case of armed forces institutes and universities, postgraduate programs. Out of these 55 universities, only 25 are accredited 
for research; therefore, they are dedicated to creating knowledge and developing intellectual capital regarding various areas of interest to the Chilean state [36,37]. The general education law in Chile [38] establishes that universities base their efforts on knowledge in order to answer to the challenges posed by laws, observing and boosting the world and its society. It is important to point out that this law contributes to various elements such as the experience, values, information, mental schemes, and processes that facilitate action, as well as being part of the human being complexity, training him or her-as well as the organization - to face and understand the great challenges of change that are often generated in the world and that impact society [39].

Following this line of research interest, in Chile, there are 31 higher education institutions dedicated to imparting hospitality, leisure, and tourism programs at a higher level [36] (Table 1); 15 universities offer undergraduate careers with degrees in hospitality, gastronomy, and tourism. However, the Universidad Austral de Chile (UACH) is the only one that has a trajectory of more than twenty years teaching this topic, incorporating a Master of Tourism Management and Innovation in its offering (the only postgraduate offering in the country) and conducting research activities [40]. Due to the above, it is possible to deduce that universities' participation in tourism research in Chile is considerably low. Many of the sector studies have been performed by the Official National Tourism Service in Chile (SERNATUR) or by independent consultant teams and academics attached to universities that do not offer tourism education programs; it is relevant to consider these as they are a strength for the industry's development.

Table 1. Universities and annual enrollment in hospitality, leisure, and tourism programs in Chile.

\begin{tabular}{|c|c|c|c|c|c|c|}
\hline Tourism Education Programs & 2015 & 2016 & 2017 & 2018 & 2019 & 2020 \\
\hline Universidad Nacional Andrés Bello & 1002 & 999 & 1108 & 1160 & 1163 & 1084 \\
\hline Ecotourism Management & 454 & 466 & 553 & 588 & 573 & 499 \\
\hline International Hospitality Manager & 150 & 160 & 173 & 189 & 195 & 176 \\
\hline Tourism and Hospitality Engineering & 398 & 373 & 382 & 383 & 395 & 409 \\
\hline Universidad Austral de Chile & 236 & 258 & 282 & 318 & 317 & 322 \\
\hline Tourism Business Management & 167 & 165 & 175 & 205 & 221 & 234 \\
\hline Master in Tourism Management and Innovation & 21 & 24 & 27 & 23 & 14 & $\mathrm{n} / \mathrm{a}$ \\
\hline Higher Technician in Nature Tourism & 48 & 69 & 80 & 90 & 82 & 88 \\
\hline Universidad Católica de la Santísima Concepción & 51 & 57 & 72 & 112 & 84 & 85 \\
\hline Higher Technician in Intercultural Gastronomy & 51 & 57 & 72 & 112 & 84 & 85 \\
\hline Universidad Católica de Temuco & 56 & 66 & 74 & 91 & 76 & 72 \\
\hline Higher Technician in Tourism & 56 & 66 & 74 & 91 & 76 & 72 \\
\hline Universidad de Aconcagua & 0 & 0 & 138 & 436 & 35 & 5 \\
\hline Higher Technician in Tourism Management & 0 & 0 & 0 & 91 & 12 & 5 \\
\hline Higher Technician in Tourism Management (S.P.) & 0 & 0 & 138 & 345 & 23 & 0 \\
\hline Universidad de la Frontera & 159 & 121 & 134 & 149 & 149 & 163 \\
\hline Higher Technician in Tourism (S.P.) & 34 & 39 & 43 & 62 & 67 & 63 \\
\hline Higher Technician in Adventure Tour Guide (S.P.) & 125 & 82 & 91 & 87 & 82 & 100 \\
\hline Universidad de la Serena & 24 & 14 & 2 & 1 & 0 & 0 \\
\hline Tourism Administration & 24 & 14 & 2 & 1 & 0 & 0 \\
\hline Universidad de las Américas & 95 & 107 & 149 & 192 & 209 & 193 \\
\hline Hospitality and Tourism & 43 & 47 & 73 & 85 & 97 & 93 \\
\hline Bachelor's Degree in Culinary Arts and Gastronomic Business & 49 & 60 & 76 & 107 & 112 & 100 \\
\hline Higher Technician in Gastronomic Business Management & 1 & 0 & 0 & 0 & 0 & 0 \\
\hline Higher Technician in Contact with Nature and Adventure Sport & 1 & 0 & 0 & 0 & 0 & 0 \\
\hline Higher Technician in Gastronomy & 1 & 0 & 0 & 0 & 0 & 0 \\
\hline Universidad de Magallanes & 41 & 62 & 60 & 73 & 69 & 62 \\
\hline Higher Technician in Tourism & 41 & 62 & 60 & 73 & 69 & 62 \\
\hline Universidad de Playa Ancha de Ciencias de la Educación & 169 & 171 & 181 & 173 & 145 & 114 \\
\hline Multilingual Tourism Administration & 169 & 171 & 181 & 173 & 145 & 114 \\
\hline Universidad de Talca & 29 & 48 & 64 & 72 & 63 & 48 \\
\hline Higher Technician in Enotourism & 29 & 48 & 64 & 72 & 63 & 48 \\
\hline
\end{tabular}


Table 1. Cont.

\begin{tabular}{|c|c|c|c|c|c|c|}
\hline Tourism Education Programs & 2015 & 2016 & 2017 & 2018 & 2019 & 2020 \\
\hline Universidad de Valparaíso & 452 & 467 & 457 & 499 & 515 & 509 \\
\hline Hospitality and Gastronomy Management & 284 & 309 & 306 & 319 & 320 & 301 \\
\hline Tourism and Culture Management & 168 & 158 & 151 & 180 & 195 & 208 \\
\hline Universidad de Viña del Mar & 13 & 28 & 53 & 71 & 83 & 64 \\
\hline Tourism and Hospitality Business Management & 13 & 28 & 53 & 71 & 83 & 64 \\
\hline Universidad del Pacífico & 25 & 15 & 7 & 3 & 0 & 0 \\
\hline Tourism Management Engineering & 25 & 15 & 7 & 3 & 0 & 0 \\
\hline Universidad Finis Terrae & 30 & 60 & 96 & 134 & 154 & 170 \\
\hline Culinary Arts Direction and Management & 30 & 60 & 96 & 134 & 154 & 170 \\
\hline Universidad Pedro de Valdivia & 15 & 7 & 3 & 0 & 0 & 0 \\
\hline Hospitality and Tourism Engineering & 15 & 7 & 3 & 0 & 0 & 0 \\
\hline Universidad San Sebastián & 336 & 388 & 426 & 479 & 471 & 455 \\
\hline Expedition and Ecotourism Engineering & 336 & 388 & 426 & 479 & 471 & 455 \\
\hline Universidad Sek & 15 & 4 & 0 & 0 & 0 & 0 \\
\hline Tourism Engineering & 15 & 4 & 0 & 0 & 0 & 0 \\
\hline Universidad Tecnológica Metropolitana & 78 & 91 & 99 & 134 & 132 & 159 \\
\hline Tourism Management Engineering & 78 & 91 & 99 & 134 & 132 & 159 \\
\hline Grand total & 2826 & 2963 & 3405 & 4097 & 3665 & 3505 \\
\hline
\end{tabular}

It is observed how enrollment in 2020 reaches a $27 \%$ concentration in ecotourism education programs, such as those offered by the Andrés Bello University (Ecotourism Management) and the University of San Sebastián (Expedition Engineering and Ecotourism), a percentage that accounts for an option for education in sustainable tourism.

\section{Materials and Methods}

Many researchers around the world have studied how publications generate changes in the knowledge world [41] and impact new research paper writing technologies [42,43]. There has also been research about how to select titles and use quotes to generate a greater impact [44-46], even by observing titles' length variation and colon use, which vary depending on the discipline [47-49]. The works by Glänzel and Thijs [50] and Franceschet, and Costantini [51] support the fact that the co-authors of an article are a reason to generate more quotes.

The above represents some of the ways in which scientometry has gained popularity over the past decades based on available documented knowledge to obtain quantitative results [52] and determine knowledge growth within various fields. To Dias et al. [53], one advantage is the capacity to work with massive data (e.g., 20 million articles published over the last three decades), managing to establish the similarity between scientific fields based on the employed linguistic bases, referenced quotes, and classification of high-impact and high-production researchers.

In terms of methodology, we analyzed the evolution and development of scientific knowledge through an economic and social approach [54-58] based on research documented on mainstream WoS journals, both the ones incorporated as emergent (ESCI) and the ones indexed to the Journal Citation Report (JCR). These last ones are recognized to have the greatest impact worldwide [59-61].

Based on spatial scientometrics [62-66] and focused on the contribution to scientific knowledge in hospitality, leisure, sport, and tourism (HLST) carried out by Chilean authors, a search vector was defined [67] that incorporated the "hospitality, leisure, sport, and tourism" and the "authors' national affiliation to Chile" knowledge categories as restrictions: WC $=$ (hospitality, leisure, sport, and tourism) and $\mathrm{CU}=$ (Chile).

As a first measure, the legitimacy of carrying out the research was determined based on observing an article collection that manages to maintain a critical mass of production between the generation of new knowledge and its obsolescence [68-71], internally identifying if it is possible to separate sport from the hospitality, leisure, sport, and tourism knowledge category and mapping the field [72,73] 
through the VOSviewer software [74] by taking into account both the thematic difference expressed by a set of "keywords plus" that manages to reduce itself into the main "keywords plus" [75] in accordance with Zipf's law [76] and the existence of potential concentrations regarding journals and prolific authors.

Bradford's Law was employed to estimate a possible adjustment of the journal concentration zones to a geometric series [77-81] in order to identify a journal concentration nucleus where Chilean authors participate in an in-depth discussion regarding hospitality, leisure, and tourism. In addition, Lotka's Law [82] was utilized to estimate author concentration and distinguish the set of prolific authors [8,83-85] following a meta-analytic scientometric approach [86] of production, impact, and relation $[58,72]$ that, relationally, focused on establishing co-authorship levels between Chile-affiliated authors and their collaborators [87,88], using VOSviewer and Pajek $[8,74,89,90]$.

\section{Results}

\subsection{Increase of Chilean Scientific Production on HLST}

The initial search vector $\{\mathrm{WC}=($ Hospitality, Leisure, Sport \& Tourism) AND CU $=($ CHILE $)\}$, limited to article documents published in mainstream journals from WoS between 1900 and 2019, resulted in a total of 167 records [91]. These records show the growth pattern over time, as it is represented in Figure 3.

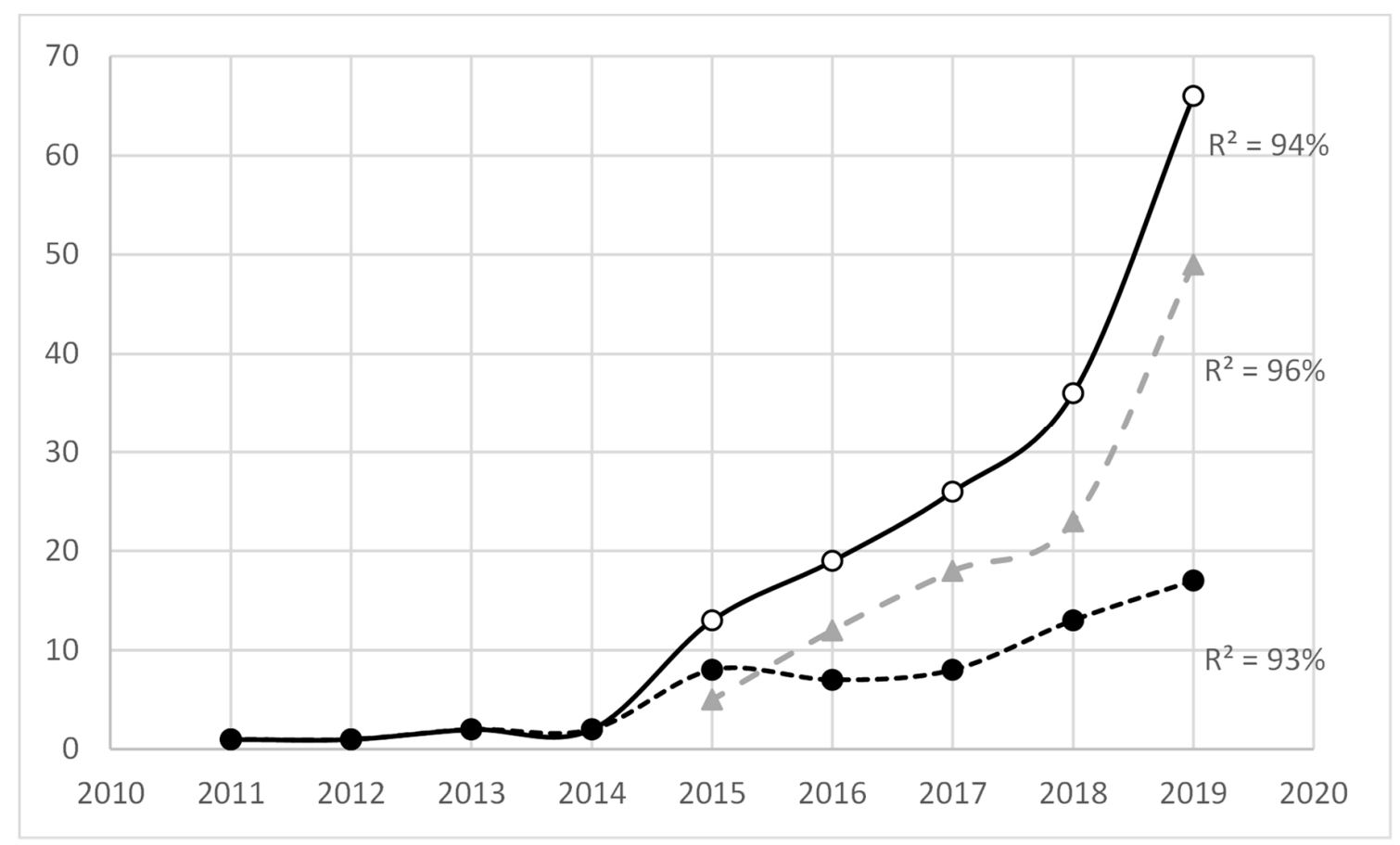

Figure 3. Increase of Chilean scientific production regarding hospitality, leisure, sport, and tourism (HLST) between 2011 and 2019.

Although there was an article published in 2009, non-negative records were presented every year from 2011 onwards. Thereby, results-wise, Figure 3 shows how the total number of articles studied are adjusted to an annual exponential growth with an R2 of $94.32 \%$, obtaining an R2 of $92.82 \%$ and $96.13 \%$ for articles published in journals indexed to JCR and ESCI, respectively. While all three curves exhibit exponential growth, there are large annual differences between the JCR and ESCI production components. Thus, the Chilean scientific production on HLST, in WoS, has evolved substantially in the last decade, but mostly in emerging journals, without an impact factor (ESCI). 


\subsection{Concentration in Relevant Publication Sources}

This concentration accounts for the journal nucleus where the discussion regarding hospitality, leisure, sport, and tourism co-produced in Chile is focused (Table 2).

Table 2. Bradford zones for hospitality, leisure, sport, and tourism journals between 2009 and 2019.

\begin{tabular}{|c|c|c|c|c|c|}
\hline \multirow{2}{*}{$\begin{array}{c}\text { Zone } \\
\text { Nucleus }\end{array}$} & \multicolumn{2}{|c|}{ \# Articles (\%) } & \multicolumn{2}{|c|}{ Journals (\%) } & \multirow[t]{2}{*}{ Bradford Multipliers } \\
\hline & 61 & $(37 \%)$ & 2 & $(4 \%)$ & \\
\hline 1 & 63 & $(38 \%)$ & 13 & $(25 \%)$ & 6.5 \\
\hline 2 & 43 & $(26 \%)$ & 36 & $(71 \%)$ & 2.8 \\
\hline Total & \multicolumn{2}{|c|}{167} & \multicolumn{2}{|c|}{51} & 4.6 \\
\hline
\end{tabular}

Thus, given a nucleus zone $a=2$ and a middle multiplier $n=4.6$, the resulting summation of the geometric series $\left(S_{S B}\right)$ in Equation (1) is equal to:

$$
S_{S B}=\sum_{i=1}^{3}\left(a * n^{i-1}\right)=2+9+43=54
$$

Margin of error $\left(\varepsilon_{p}\right)$ in Equation (2) of:

$$
\varepsilon_{p}=\left(\frac{(\text { Real }- \text { Estimated })}{\text { Real }}\right) * 100=\left(\frac{(51-54)}{51}\right) * 100=6.3 \%
$$

Although this error is not too high [80], it will be at least considered as high due to high concentration in the nucleus and zone 1 . Thereby, the subset containing two journals with the highest number of published articles (nucleus) and the following zone 1-15 journals between the two will be regarded as relevant Bradford zones for the WoS category study over the defined period of time, as it is observed in Table 3.

\begin{tabular}{|c|c|c|c|c|c|}
\hline Source (Journals) & \# Articles & $\%$ of 167 & Index & Qx in HLST & Only HLT \\
\hline $\begin{array}{c}\text { Retos-Nuevas Tendencias en Educación Física } \\
\text { Deporte y Recreación }\end{array}$ & 39 & $23 \%$ & ESCI & - & - \\
\hline Journal of Sport and Health Research & 22 & $13 \%$ & ESCI & - & - \\
\hline Pasos-Revista de Turismo y Patrimonio Cultural & 8 & $5 \%$ & ESCI & - & Yes \\
\hline International Journal of Hospitality Management & 6 & $4 \%$ & SSCI & Q1 & Yes \\
\hline International Journal of Tourism Research & 6 & $4 \%$ & SSCI & Q2 & Yes \\
\hline Tourism Economics & 6 & $4 \%$ & SSCI & Q4 & Yes \\
\hline Tourism Management & 6 & $4 \%$ & SSCI & Q1 & Yes \\
\hline $\begin{array}{l}\text { IDO Movement for Culture-Journal of Martial } \\
\text { Arts Anthropology }\end{array}$ & 5 & $3 \%$ & ESCI & - & - \\
\hline Journal of Tourism and Cultural Change & 4 & $2 \%$ & SSCI & Q3 & Yes \\
\hline Arrancada & 4 & $2 \%$ & ESCI & - & - \\
\hline Cuadernos de Turismo & 4 & $2 \%$ & ESCI & - & Yes \\
\hline Cultura Ciencia y Deporte & 4 & $2 \%$ & ESCI & - & - \\
\hline E-Balonmano COM & 4 & $2 \%$ & ESCI & - & - \\
\hline Journal of Destination Marketing \& Management & 3 & $2 \%$ & SSCI & Q1 & Yes \\
\hline Journal of Sport and Health Science & 3 & $2 \%$ & $\begin{array}{l}\text { SCIE, } \\
\text { SSCI }\end{array}$ & Q1 & - \\
\hline
\end{tabular}

Table 3. Bradford zones for hospitality, leisure, sport, and tourism journals between 2009 and 2019.

Below, Table 4 details in an evolutionary way the Chilean scientific production in only HLT journals that are part of the Bradford nucleus and zone 1. 
Table 4. Articles in hospitality, leisure, and tourism (HLT) journals between 2009 and 2019.

\begin{tabular}{ccccccc}
\hline Source (Journals) & 2009-2011 & $\mathbf{2 0 1 2 - 2 0 1 4}$ & $\mathbf{2 0 1 5 - 2 0 1 7}$ & 2018-2019 & \# Articles & Index \\
\hline Pasos-Revista de Turismo y Patrimonio Cultural & 0 & 0 & 2 & 6 & 8 & ESCI \\
\hline International Journal of Hospitality Management & 0 & 0 & 2 & 4 & 6 & SSCI/Q1 \\
\hline International Journal of Tourism Research & 0 & 0 & 4 & 2 & 6 & SSCI/Q2 \\
\hline Tourism Economics & 0 & 2 & 2 & 2 & 6 & SSCI/Q4 \\
\hline Tourism Management & 0 & 1 & 5 & 0 & 6 & SSCI/Q1 \\
\hline Journal of Tourism and Cultural Change & 0 & 1 & 0 & 3 & 4 & SSCI/Q3 \\
\hline Cuadernos de Turismo & 0 & 0 & 1 & 3 & 4 & ESCI \\
\hline Journal of Destination Marketing \& Management & 0 & 0 & 2 & 1 & SSCI/Q1 \\
\hline All Journals (nucleus and zone 1) & 0 & 4 & 18 & 21 & 43 & - \\
\hline Articles in Journals Q1 + Q2 & $0 \%$ & $25 \%$ & $72 \%$ & $24 \%$ & $49 \%$ & - \\
\hline
\end{tabular}

The table above shows the evolution of publications affiliated with Chile and their passage in a decade from zero to forty-three papers in WoS, with almost $50 \%$ of them in the world's highest quality journals for HLT.

\subsection{Research Topics within the WoS HLST Category}

To analyze the research topics within the WoS HLST category, the keywords designated by WoS or "keyword plus" are reviewed. Since this set presents 494 words, following Zipf's law, thematic concentration spheres that approximate a total of 22 and 5 words are established [91]. In Figure 4, 463 consistently connected words are represented through VOSviewer. The red spheres stand out. In Figure 4, it can be observed that the sports theme concentrates on the right of the map, distanced from the recurrent topics regarding hospitality, leisure, and tourism. Thus, the search vector, although generic, provides possibilities to isolate both topics.

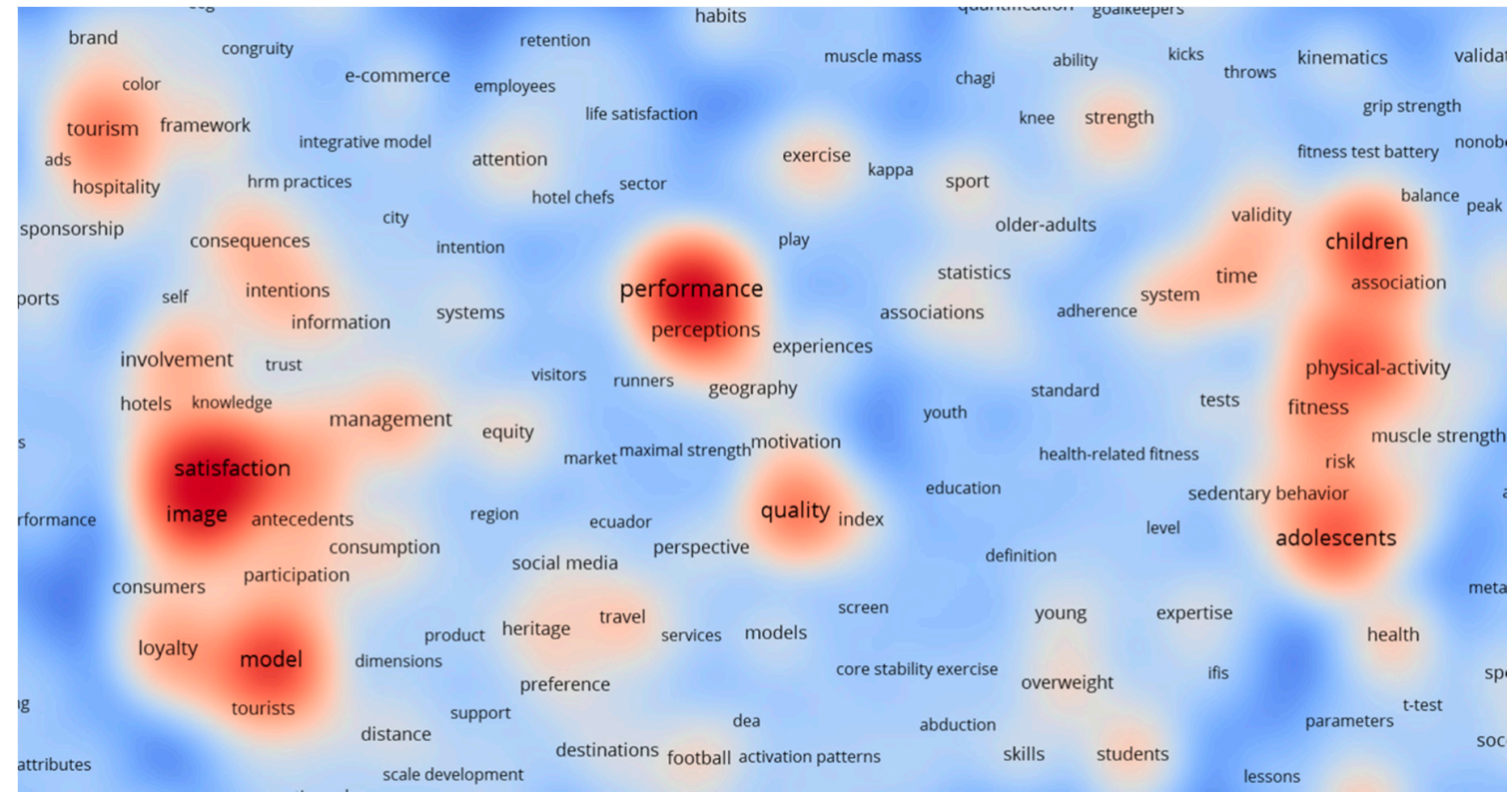

Figure 4. Thematic heat map based on "keywords plus". 
Isolating the sports theme, by segregation of journals, a set reduced to 69 articles (see Appendix A) that contains 312 authors keywords was identified, and VOSviewer can consistently connect 144, allowing one to visualize the thematic evolution over time in Figure 5. For example, between 2011 and 2014, the themes of the five articles (purple spheres) referred to tourism statistics, travelers' loyalty, travelers' motivations, destination branding, construction (of place), cruise industry, and sustainable tourism. In addition to an accumulation of other market terms such as sttrition bias, authenticity, consumer-based brand equity, commitment, commodification, identity, and satisfaction.

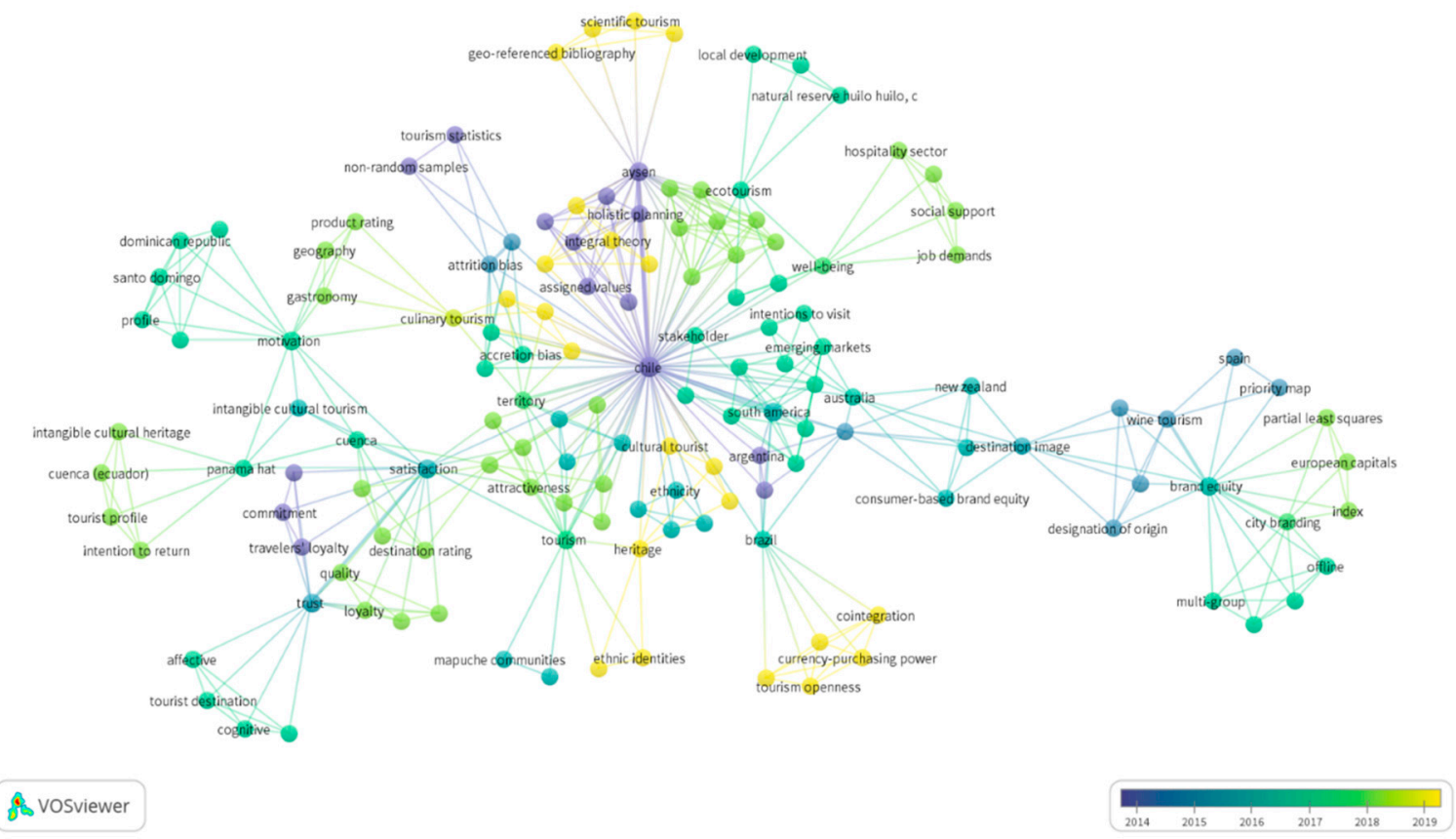

Figure 5. Thematic temporal map based on author keywords (only HLT without sports).

Instead, in 2019, more specific sectoral terms emerged (yellow spheres): culinary tourism, cultural tourist, hospitality industry, hospitality management, hotel sector, recreational services, resident perception, scientific tourism, social dancing, space-time paths, tourism growth, tourism impacts, tourism openness, tourist experience, and tourist spaces. Others denote a thematic evolution closer to sustainable tourism [60] in the Sustainable Development Goals (SDG) framework, such as cointegration, cultural change, customer-to-customer interactions, electricity consumption, ethnic identities, heritage, holistic planning, human dimension, indigenous people, innovation capacity, integral theory, natural area value scale, otherness, patrimonialization, performance, physical/mental health, presenteeism, protected area conflict, protected area management, psychological wellbeing, quality certification, territory, trade openness, value co-creation, working conditions, and worldview.

\subsection{Co-Authorship of Chilean Scientific Production Regarding HLST}

To review co-authorship, 485 prolific authors that participated in the set of 167 articles were analyzed [91]. Approximately 22 of these authors were considered (Square Root (485)). However, due to the production similarity of three articles, this number was extended to 40 authors, as is presented in Figure 6.

The network includes 12 clusters. One of them was disregarded due to its emphasis on sports. The set of prolific authors exclusively devoted to hospitality, leisure, and tourism (HLT) is presented below (Table 5). 


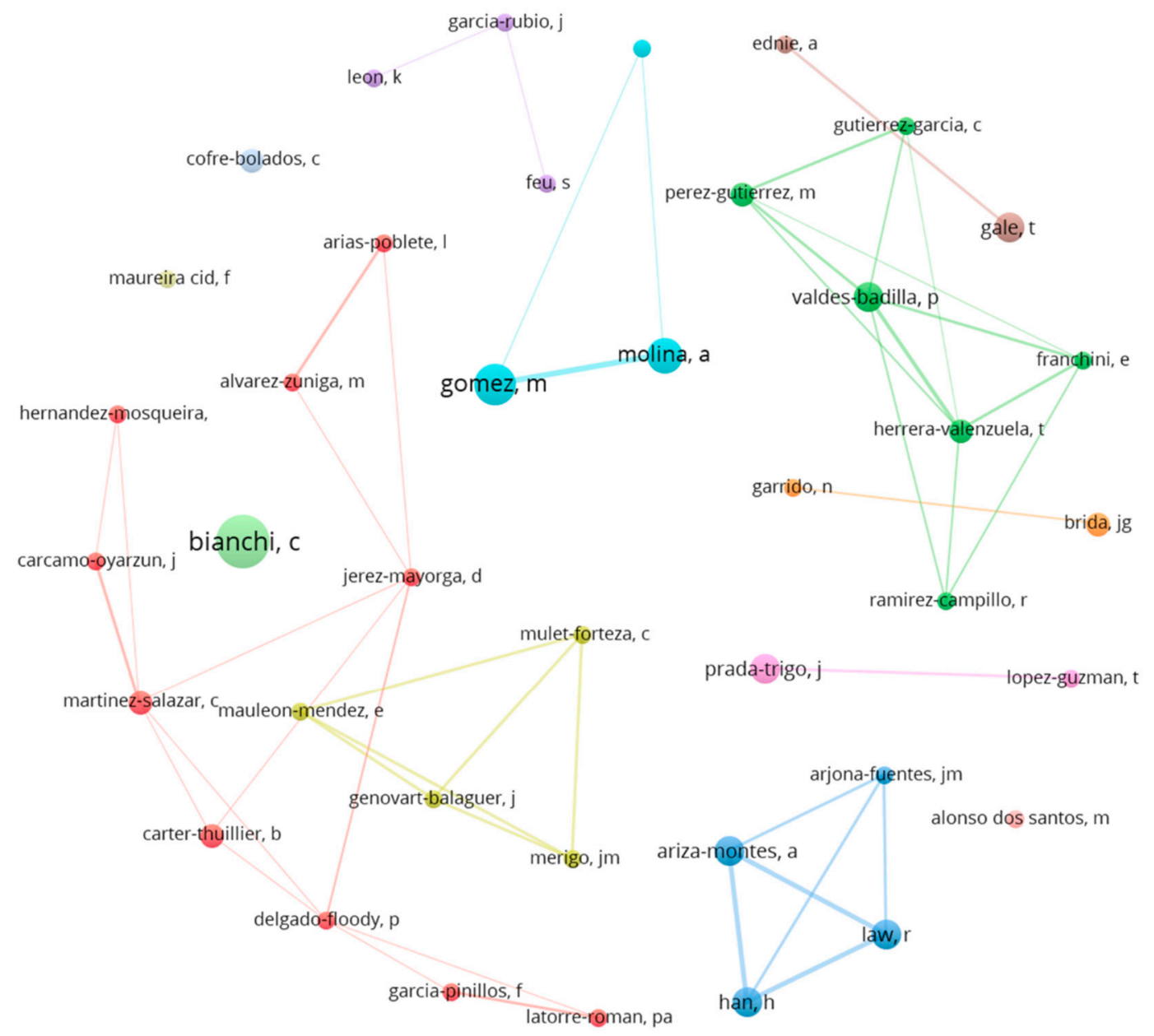

Figure 6. Network of prolific authors of scientific production on HLST.

Table 5. Prolific authors of Chilean production on HLT.

\begin{tabular}{|c|c|c|c|c|c|c|c|}
\hline Author & Articles WoS & Citations in WoS & ESCI & JCR & JCR-Q1 & Affiliation Country & $\begin{array}{c}\text { Local Affiliation } \\
\text { University/Research Center }\end{array}$ \\
\hline Bianchi, C & 9 & 146 & 2 & 7 & 3 & $\mathrm{CL}$ & U. Adolfo Ibáñez (UAI) \\
\hline Gómez, M & 7 & 69 & 0 & 7 & 5 & $\mathrm{CL}, \mathrm{ES}$ & U. Autónoma de Chile (UA) \\
\hline Molina, A & 6 & 62 & 0 & 6 & 5 & $\mathrm{CL}, \mathrm{ES}$ & U. Autónoma de Chile (UA) \\
\hline Ariza-Montes, A & 5 & 14 & 0 & 5 & 5 & $\mathrm{CL}, \mathrm{ES}$ & U. Autónoma de Chile (UA) \\
\hline Han, $\mathrm{H}$ & 5 & 14 & 0 & 5 & 5 & $\mathrm{KR}$ & \\
\hline Law, R & 5 & 14 & 0 & 5 & 5 & HK & \\
\hline Gale, $\mathrm{T}$ & 5 & 12 & 1 & 4 & 1 & CL & $\begin{array}{c}\text { Patagonian Ecosystems } \\
\text { Investigation Research } \\
\text { Center (CIEP) }\end{array}$ \\
\hline Prada-Trigo, J & 5 & 5 & 4 & 1 & 0 & $\mathrm{CL}$ & U. de Concepción (UdeC) \\
\hline Brida, JG & 4 & 45 & 0 & 4 & 0 & IT, UY & \\
\hline Garrido, N & 3 & 38 & 0 & 3 & 0 & $\mathrm{CL}$ & $\begin{array}{l}\text { U. Diego Portales (UDP)/U. } \\
\text { Católica del Norte (UCN) }\end{array}$ \\
\hline Genovart-Balaguer, J & 3 & 15 & 1 & 2 & 2 & ES & \\
\hline Mauleon-Mendez, E & 3 & 15 & 1 & 2 & 2 & ES & \\
\hline Merigo, JM & 3 & 15 & 1 & 2 & 2 & $\mathrm{CL}, \mathrm{AU}$ & U. de Chile (UCH) \\
\hline Mulet-Forteza, C & 3 & 15 & 1 & 2 & 2 & ES & \\
\hline Martin-Consuegra, D & 3 & 14 & 0 & 3 & 1 & $\mathrm{CL}, \mathrm{ES}$ & U. Autónoma de Chile (UA) \\
\hline Arjona-Fuentes, JM & 3 & 12 & 0 & 3 & 3 & ES & \\
\hline Ednie, A & 3 & 4 & 1 & 2 & 1 & US & \\
\hline Lopez-Guzman, T & 3 & 4 & 3 & 0 & 0 & ES & \\
\hline
\end{tabular}

WoS-Web of Science. 
Thus, nine prolific authors with Chilean affiliation were observed. There was a high concentration of Spanish researchers (6) mainly with training in universities belonging to REDINTUR (Universidad de Castilla la Mancha, Universidad de Barcelona, and Universidad Complutense de Madrid) [92], an American, a Chilean with studies in Australia and a Chilean with studies in Spain. The training of these prolific authors is concentrated in the economic sciences area with seven researchers, the exceptions being a Ph.D. in forest resource science and a Ph.D. in human geography.

Additionally, scientific production by Chilean-affiliated authors in 2020 presents nine articles. Six of these are in WoS-ESCI journals, contributions from Universidad de La Frontera [93,94], Universidad Austral de Chile [95,96], Universidad del Desarrollo [97], and Universidad de Chile [98]. Three works stand out in the WoS-JCR index. These are locally affiliated to Universidad Técnica Federico Santa María [99] and Universidad Autónoma de Chile [8,100].

From a thematic approach, the nine prolific authors identified were associated with a subset of 39 articles (Appendix B), which are described thematically by 185 author keywords, with only 18 that are repeated at least once: Chile (9 records), brand equity (4), Aysen (3), bibliometrics (3), motivation (3), satisfaction (3), South America (3), Cuenca (3), Australia (2), city branding (2), cultural tourism (2), destination branding (2), destination image (2), holistic planning (2), hospitality industry (2), Panama hat (2), vos viewer (2), and wine tourism (2). All are drawn as green triangles in Figure 7.

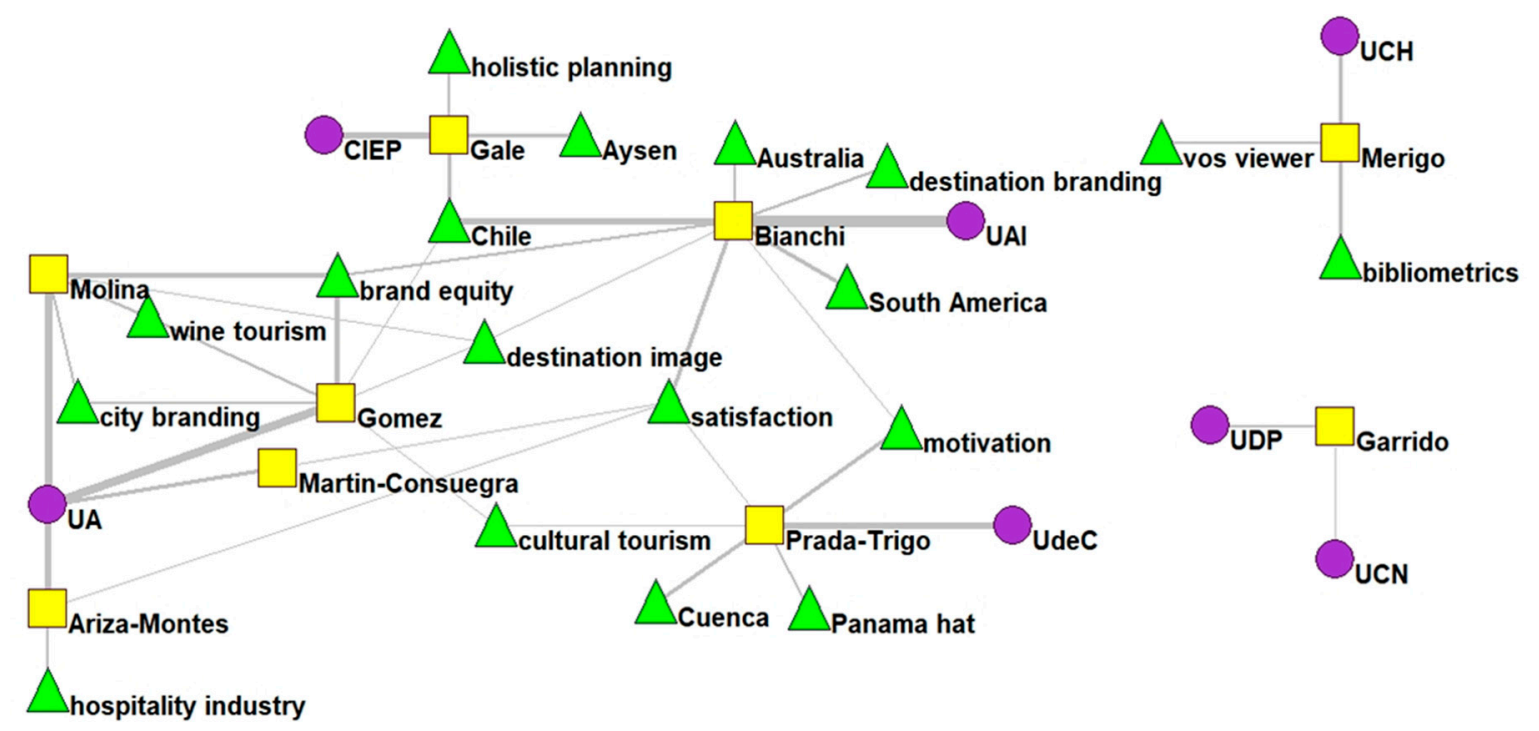

Figure 7. Network of prolific authors (yellow box), Chilean affiliation (purple circle), and authors keywords (green triangle) on HLT scientific production.

In terms of these author keywords, Figure 7 points out as a disconnected authors Garrido, Ph.D. (UDP, before UCN), and Merigo, Ph.D. (UCH), Gale, Ph.D. is oriented to sustainability issues, while Prada-Trigo, Ph.D. (UdeC) is linked by the cultural tourism studies and the concepts motivation and satisfaction to Bianchi, Ph.D. (UAI) and authors of the UA (Ariza-Montes, Gómez, and Martin-Consuegra). Ariza-Montes, Ph.D. (UA) focuses on hospitality issues, and Molina, Ph.D. and Gómez, Ph.D. maintain wine tourism and city branding as common themes, their interest in marketing (branding) being shared with Bianchi, $\mathrm{Ph}$.D. Finally, the localities studies (cities, countries, and regions) show an explicit association between Bianchi, Ph.D.; Gale, Ph.D.; and Gómez, Ph.D. with studies about Chile. The topics (TS) addressed by these authors-tourism marketing (TM), cultural tourism (CT), wine/oenological tourism (WT), hospitality industry (HI), and sustainable tourism (ST) - present increasing trends in the number of articles published in the WoS HLST category (WC) in the last decade (2010-2019), in Figure 8. 


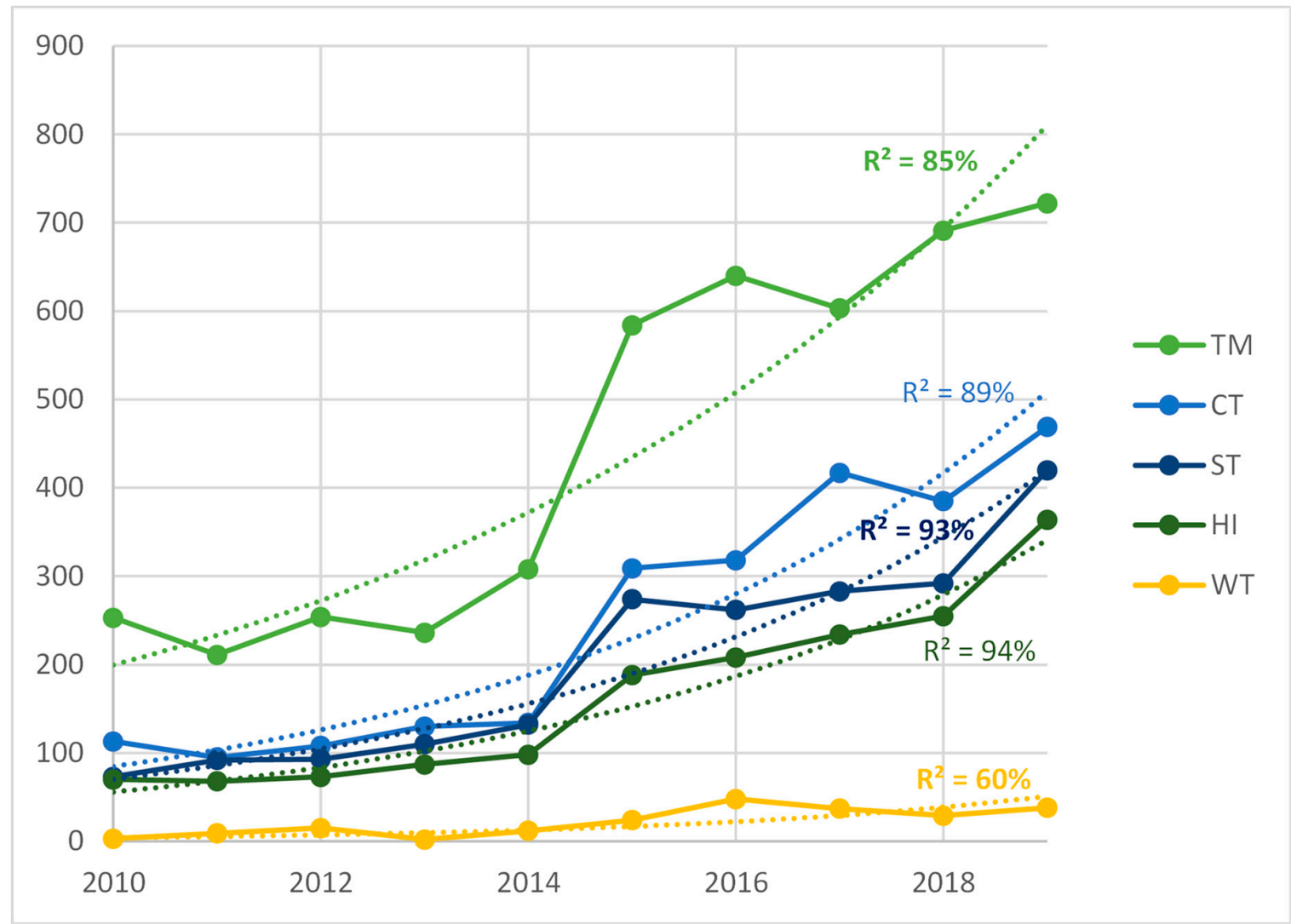

Figure 8. Topics evolution (TS) in the WoS Category (WC) hospitality, leisure, sport, and tourism category (2010-2019). TM—-tourism marketing, CT—cultural tourism, WT—wine/oenological tourism, HI-hospitality industry, ST—sustainable tourism.

\section{Discussion}

The bibliometric and scientometric analysis on hospitality, leisure, and tourism presented establishes the role of this field's entities (individuals, groups, and institutions) regarding Chilean-affiliated articles, which present today high growth in quantity, quality, and maturity themes [68], achieving scientific critical mass [101].

First of all, the results contribute to widening the discourse about hospitality, leisure, and tourism research through the integrated use of classical bibliometric laws and various scientometric techniques, as well as covering production, impact and relation, laws, and techniques commonly used-with lack of synergy-in the research on hospitality, leisure, and tourism topics $[59,60,70,71,84,87,88]$.

Secondly, research conducted by authors like Qian, Law, Wei, and Wu [13] highlight high-impact academic works on hospitality, leisure, and tourism, particularly regarding this scientific subdiscipline's structure in one of the highest research stages worldwide, thus obtaining, as a result, that the Tourism Management (TM) and International Journal of Hospitality Management (IJHM) journals are among the most relevant journals globally. Both of these stand out among the highest-impact journals where research teams affiliated to a Chilean author or organization have managed to publish—six articles published in each of these journals. As for prominent authors, they identify Dr. Law himself, who also contributes alongside Chilean-affiliated authors.

Thirdly, Martorell-Cunill, Socias-Salvá, Gonzalez, and Mulet-Forteza [102] identify, among the best journals in the field, five journals with Chilean-affiliated production: International Journal of Hospitality Management, Tourism Management, Journal of Destination Marketing \& Management, Tourism Economics, and International Journal of Tourism Research. Furthermore, Dr. Law (Hong Kong Polytechnic University, HK SAR China) and Dr. Han (Sejong University, KR) stand out as the best authors worldwide; both of them are collaborators with Chilean-affiliated productions indexed to WoS-JCR. 
Lastly, in regard to gender perspective on hospitality, leisure, and tourism research, Figueroa-Domecq, Pritchard, Segovia-Pérez, Morgan, and Villacé-Molinero [103] and Nunkoo, Thelwall, Ladsawut, and Goolaup [104] point out that, out of six Chilean-affiliated authors that have managed to publish on first quartile (Q1) journals for this topic, such as WoS and JCR, three of them are women: C. Bianchi, M. Gomez, and T. Gale.

Additionally, the present research presents network analyses to explore and visualize the relation between highly quoted authors and works from hospitality, leisure, and tourism journals—such is the case of Martorell-Cunill, Socias-Salvá, Gonzalez, and Mulet-Forteza [102]. These networks identify academics and works that are within specific disciplinary domains (in this case, cultural tourism, wine tourism, destination branding, and the hospitality industry) as well as works that have interdisciplinary and post-disciplinary influence [105]. This finding highlights that tourism research integrates distinctive components from other disciplines (in this case, marketing and sustainability) to create new knowledge, such as tourism marketing and sustainable tourism. In addition, relational analysis is added to previous evaluations, studies, and qualitative review articles that are mainly based on observations and reflections. A good part of tourism research has been developed by universities that do not have undergraduate and/or postgraduate training programs on hospitality, leisure, and tourism, but rather research teams that work on various areas of the regional reality and that tangentially cover research from this economic sector-such is the case of Pontificia Universidad Católica de Valparaíso and its Institute of Geography [106,107], Universidad del Bío Bío in Concepción [108], and Universidad Autónoma de Chile [109-114].

Due to the multipurpose character-coincident with the interdisciplinarity of hospitality, leisure, and tourism research-of these groups of researchers, they do not make systematic and permanent efforts regarding this subdiscipline, nor do they have the necessary association with the rest of the national industry's actors. In these cases, research does not respond to an organic program offered by the universities and its development in the country is still significantly low, so there is no relationship between the importance of the sector and the resources allocated to research. However, when there are competitive funds for research, an important responsibility lies on the academics' interest [55] and the presentation of interesting and well-structured projects that meet all the scientific requirements for a successful application.

\section{Conclusions}

This research analyzed the progress of hospitality, leisure, and tourism studies in Chile with data collected from the Web of Science (WoS), based on hospitality, leisure, and tourism journals that lead and are positioned on top of this subdiscipline worldwide. The findings offer clear theoretical and practical implications by approaching the studies' progress, such is the case of scientific production by Chilean-affiliated authors.

Research on hospitality, leisure, and tourism in Chile is still growing. This growth is at a level that can identify local critical mass (capacity for the production of scientific knowledge in the subdiscipline, reflected in an exponential growth in the number of articles published), but geographically, thematically, and institutionally dispersed. Proof of this is that, by the first semester of 2020, there already were nine articles in the WoS. Six of these articles were published in WoS-ESCI journals that approached topics such as rural tourism entrepreneurship in ethnic territories and tourist demand modeling and forecasting at a regional level. The three remaining articles were published in journals indexed to WoS-JCR concerning the aesthetic assessment of natural plants within the environment where hospitality service is developed and the global research benchmarks for cruise tourism, in addition to work engagement and well-being of cruise ship employees, connecting with Brida et al. [115] in the Blue Economy. The latter three articles were published in high academic relevance journals by researchers, bringing Chile up to almost ninety articles of this quality level to contribute world knowledge in HLT in the last decade. There were from universities that, to date, do not offer hospitality, 
leisure, and tourism education programs, theoretically emphasizing the need for research to connect with education, to generate the changes that the industry requires for a more sustainable development.

Despite the above, the growth shown has given quality signs by achieving publications in the journals with the highest global reputation in the sub-discipline and by establishing incipient collaborations with the main researchers worldwide in this area. A thematic maturity has been reached with emphasis on specific disciplinary domains such as tourism marketing, cultural and oenological tourism, and the hospitality industry, recently adding the cruise industry and sustainable tourism. The latter is associated with the education concentration in ecotourism and the research carried out at Patagonian Ecosystems Investigation Research Center (CIEP) in the Austral region of Chile. This local knowledge generated in HLT strengthens sectoral public policies and achieves better development of the industry, which contributes to the sustainable economy of the country.

There is significant distancing between university centers of mainstream knowledge production and centers that offer university education. This results in two questions worthy of further exploration in the future education public policies studies at the global level. What knowledge is reproduced by those who are not capable of generating knowledge? Why do those who produce relevant knowledge fail to manage it in order to spread it through teaching and incorporate it into the local hospitality, leisure, and tourism industry? Within the HLST studies there is a great volume of knowledge in sports; it is of interest to know how this knowledge contributes to health and education public policies of different countries.

Author Contributions: Conceptualization, A.V.-M.; methodology, A.V.-M.; software, A.V.-M.; validation, G.S.-S.; formal analysis, A.V.-M.; data curation, A.V.-M.; writing—original draft preparation, Á.A.-D.; writing-review and editing, G.S.-S.; supervision, A.V.-M.; project administration, Á.A.-D.; funding acquisition, G.S.-S. All authors have read and agreed to the published version of the manuscript.

Funding: The APC was partially funded by Universidad Católica de la Santísima Concepción.

Conflicts of Interest: The authors declare no conflict of interest.

\section{Appendix A}

Search vector for the recovery of 69 articles with segregation of journals only HLT: UT = (WOS:000497872100009 OR WOS:000510156300015 OR WOS:000494910600001 OR WOS:000504670100010 OR WOS:000483615200007 OR WOS:000494883100019 OR WOS:000494883100022 OR WOS:000477531100001 OR WOS:000503224000010 OR WOS:000503224000013 OR WOS:000475253500001 OR WOS:000463744600009 OR WOS:000465172000003 OR WOS:000460194600006 OR WOS:000456199500004 OR WOS:000447566200007 OR WOS:000455952600008 OR WOS:000441100200003 OR WOS:000447195300010 OR WOS:000447195300007 OR WOS:000440529800002 OR WOS:000438346500012 OR WOS:000441953200002 OR WOS:000434648100006 OR WOS:000432532100006 OR WOS:000429392300020 OR WOS:000467037400022 OR WOS:000423639900011 OR WOS:000452703000009 OR WOS:000445342800007 OR WOS:000444259600005 OR WOS:000443323700005 OR WOS:000441347300002 OR WOS:000432678300004 OR WOS:000419094400002 OR WOS:000419415200006 OR WOS:000417383200007 OR WOS:000412755100005 OR WOS:000403984600017 OR WOS:000417645000013 OR WOS:000416392000003 OR WOS:000390739400030 OR WOS:000391801500006 OR WOS:000390642800003 OR WOS:000423902100001 OR WOS:000418705500007 OR WOS:000409184900001 OR WOS:000396371400005 OR WOS:000388668000013 OR WOS:000411939600004 OR WOS:000379030100007 OR WOS:000377895300008 OR WOS:000374850000002 OR WOS:000371746000010 OR WOS:000396634300003 OR WOS:000395465400001 OR WOS:000369195300006 OR WOS:000367268800006 OR WOS:000367498300007 OR WOS:000364731900023 OR WOS:000361162000007 OR WOS:000357553100005 OR WOS:000350710600030 OR WOS:000352908500009 OR WOS:000333000100024 OR WOS:000326866600002 OR WOS:000318199900014 OR WOS:000303791100010 OR WOS:000300017900005). 


\section{Appendix B}

Search vector for the recovery of 39 articles published by prolific authors affiliated with Chilean institutions, segregating journals only HLT: UT = (WOS:000303791100010 OR WOS:000326866600002 OR WOS:000333000100024 OR WOS:000350710600030 OR WOS:000352908500009 OR WOS:000357553100005 OR WOS:000361162000007 OR WOS:000364731900023 OR WOS:000367268800006 OR WOS:000367498300007 OR WOS:000371746000010 OR WOS:000390642800003 OR WOS:000390739400030 OR WOS:000396371400005 OR WOS:000396634300003 OR WOS:000412755100005 OR WOS:000417383200007 OR WOS:000419094400002 OR WOS:000423639900011 OR WOS:000423902100001 OR WOS:000429392300020 OR WOS:000432532100006 OR WOS:000432678300004 OR WOS:000438346500012 OR WOS:000440529800002 OR WOS:000441100200003 OR WOS:000441347300002 OR WOS:000443323700005 OR WOS:000444259600005 OR WOS:000445342800007 OR WOS:000452703000009 OR WOS:000467037400022 OR WOS:000475253500001 OR WOS:000477531100001 OR WOS:000483615200007 OR WOS:000494883100019 OR WOS:000494883100022 OR WOS:000497872100009 OR WOS:000510156300015).

\section{References}

1. Marujo, M.N.N.V. A internet como novo meio de comunicação para os destinos Turísticos: O caso da Ilha da Madeira. Rev. Tur. Anál. 2008, 19, 25-42. [CrossRef]

2. Cacho, A.D.N.B.; de Azevedo, F.F. O turismo no contexto da sociedade informacional. Rev. Bras. Pesqui. Tur. 2010, 4, 31-48. [CrossRef]

3. Vargas-Sánchez, A. ¿Los principales destinos son también las principales potencias en la investigación en turismo? Estud. Turísticos 2011, 188, 91-111.

4. Esteves, E.T.; Fernandes, P.O. Perfil do visitante praticante de atividades de animação turística da região alto Trás-os-Montes. Gestin 2016, 12, 149-162.

5. Hall, C.M. Publish and perish? Bibliometric analysis, journal ranking and the assessment of research quality in tourism. Tour. Manag. 2011, 32, 16-27. [CrossRef]

6. Majeed, S.; Zhou, Z.; Lu, C.; Ramkissoon, H. Online tourism information and tourist behavior: A structural equation modeling analysis based on a self-administered survey. Front. Psychol. 2020, 11, 599. [CrossRef]

7. Baggio, R. Big Data e turismo: Una relazione complicata. In XXIII Rapporto sul Turismo Italiano-2018/2019; Becheri, E., Morvillo, A., Eds.; CNR-IRISS—Rogiosi Editore: Napoli, Italy, 2019; pp. 91-106.

8. Vega-Muñoz, A.; Arjona-Fuentes, J.M.; Ariza-Montes, A.; Han, H.; Law, R. In search of 'a research front' in cruise tourism studies. Int. J. Hosp. Manag. 2020, 85, 102353. [CrossRef]

9. Pike, S.; Bianchi, C.; Kerr, G.; Patti, C. Consumer-based brand equity for Australia as a long-haul tourism destination in an emerging market. Int. Market. Rev. 2010, 27, 434-449. [CrossRef]

10. Flamarich, M.; Duro, J.A. Turismo de negocios (eventos) en España: Análisis y perspectivas. Pap. Tur. 2014, $49,59-75$.

11. Villena-Navarro, M. Turismo de negocios: Análisis del gasto diario de los turistas de negocios. Anu. Jóvenes. Investig. 2014, 7, 78-80.

12. Altbach, P.; Peterson, P.M. Educación Superior en el Siglo XXI: Desafío Global y Respuesta Nacional; Editorial Biblos: Buenos Aires, Argentina, 2000; pp. 10-22.

13. Qian, J.; Law, R.; Wei, J.; Wu, Y. Trends in Global Tourism Studies: A Content Analysis of the Publications in Tourism Management. J. Qual. Assur. Hosp. Tour. 2019, 20, 753-768. [CrossRef]

14. Szmulewicz-Espinosa, P. Universidad e investigación turística en Chile. Rev. Tur. Anál. 1998, 9, 107-122. [CrossRef]

15. UNWTO. World Tourism Barometer and Statistical Annex January 2020. Available online: https://doi.org/10. 18111/wtobarometereng.2020.18.1.1 (accessed on 26 July 2020).

16. UNWTO. World Tourism Barometer and Statistical Annex December 2019. Available online: https: //www.unwto.org/world-tourism-barometer-2019-nov (accessed on 26 July 2020).

17. UNWTO. International Tourist Arrivals Could Fall by 20-30\% in 2020. Available online: https://www.unwto. org/news/international-tourism-arrivals-could-fall-in-2020 (accessed on 8 August 2020).

18. Gössling, S.; Scott, C.D.; Hall, M. Pandemics, tourism and global change: A rapid assessment of COVID-19. J. Sustain. Tour. 2020. [CrossRef] 
19. Mato, D. Diversidad Cultural e Interculturalidad en Educación Superior. Experiencias en América Latina; United Nations Educational, Scientific and Cultural Organization: Caracas, Venezuela, 2018; pp. 42-48.

20. Hemsley-Brown, J.; Lowrie, A.; Gruber, T.; Fuß, S.; Voss, R.; Gläser-Zikuda, M. Examining student satisfaction with higher education services. Int. J. Pub. Sect. Manag. 2010, 23, 105-123.

21. Rodríguez-Ponce, E. The role of universities in the knowledge society and in the era of globalization: Evidence from Chile. Interciencia 2009, 34, 822-829.

22. Newell, S.; Scarbrough, H.; Swan, J.; Robertson, M.; Galliers, R. The Importance of Process Knowledge for Cross Project learning: Evidence from a UK Hospital. In Proceedings of the 35th Hawaii International Conference on System Sciences, Big Island, HI, USA, 10 January 2002; Sprague, R.J., Ed.; IEEE: Los Alamitos, CA, USA, 2002; pp. 1019-1028.

23. Quiroz-Rodríguez, J.; Ramírez-Magdaleno, J.A.; Membrila-Cortés, P.A. Análisis comparativo de la administración de la relación con los clientes en la industria hotelera en Jalisco y Nayarit. Riico 2009, 3, 1840-1856.

24. Lee, H.; Choi, B. Knowledge management enablers, processes, and organizational performance: An integrative view and empirical examination. J. Manag. Inf. Syst. 2003, 20, 179-228.

25. Liao, S.H. Knowledge management technologies and applications-Literature review from 1995 to 2002. Expert Syst. Appl. 2003, 25, 155-164. [CrossRef]

26. Cheng, C.K.; Li, X.R.; Petrick, J.F.; O’Leary, J.T. An examination of tourism journal development. Tour. Manag. 2011, 32, 53-61. [CrossRef]

27. Huang, S. Tourism as the subject of China's doctoral dissertations. Ann. Tour. Res. 2011, 38, 316-319. [CrossRef]

28. Meyer-Arendt, K.J.; Justice, C. Tourism as the Subject of North American. Ann. Tour. Res. 2002, 29, 1171-1174. [CrossRef]

29. Benckendorff, P.; Zehrer, A. A network analysis of tourism research. Ann. Tour. Res. 2013, 43, 121-149. [CrossRef]

30. Gloet, M.; Samson, D. Knowledge Management and Systematic Innovation Capability. In Disruptive Technology: Concepts, Methodologies, Tools, and Applications; Information Resources Management Association, Ed.; IGI-Global: Hershey, PA, USA, 2020; pp. 1198-1218.

31. Jakubik, M. Capturing Knowledge Co-Creation with the Practice Ecosystem Framework in Business and Academia Collaboration. Int. J. Manag. Rev. Knowl. Learn. 2019, 1, 95-114.

32. Köseoglu, M.A.; Rahimi, R.; Okumus, F.; Liu, J. Bibliometric studies in tourism. Ann. Tour. Res. 2016, 61, 180-198. [CrossRef]

33. Dayan, R.; Heisig, P.; Matos, F. Knowledge management as a factor for the formulation and implementation of organization strategy. J. Knowl. Manag. 2017, 21, 308-329. [CrossRef]

34. Jain, R.; Sahney, S.; Sinha, G. Developing a Scale to Measure Students' Perception of Service Quality in the Indian Context. TQM J. 2013, 25, 276-294. [CrossRef]

35. Rivera-Porras, D. Aproximaciones conceptuales del aprendizaje organizacional. AiBi Rev. Investig. Adm. Ing. 2019, 7, 20-25. [CrossRef]

36. CNED. Indices DB Registration. Available online: https://www.cned.cl/bases-de-datos (accessed on 26 July 2020).

37. Ministry of Education. About Higher Education; Government of Chile: Santiago de Chile, Chile, 2019; pp. 1-101.

38. Ministry of Education. Fixed Consolidated, Coordinated and Systematized Text of Law $N^{\circ} 20.370$ with the Non-Repealed Norms of the Decree with Force of Law N N 1, of 2005; Government of Chile: Santiago, Chile, 2019; pp. 1-48.

39. González-Millán, J.J.; Rodríguez-Díaz, M.T. Modelos de Capital Intelectual y sus indicadores en la universidad pública. Cuad. Adm. 2010, 43, 113-128. [CrossRef]

40. Skewes, J.C.; Henríquez-Zuñiga, C.; Pilquimán-Vera, M. Turismo comunitario o de base comunitaria: Una experiencia alternativa de hospitalidad vivida en el mundo mapuche. Tralcao sur de Chile. Cult. Rev. Cult. Tur. 2012, 6, 73-85.

41. Missen, M.M.S.; Qureshi, S.; Salamat, N.; Akhtar, N.; Asmat, H.; Coustaty, M.; Prasath, V.S. Scientometric analysis of social science and science disciplines in a developing nation: A case study of Pakistan in the last decade. Scientometrics 2020, 123, 113-142. [CrossRef]

42. Hartley, J.; Howe, M.; McKeachie, W. Writing through time: Longitudinal studies of the efects of new technology on writing. Br. J. Educ. Technol. 2001, 32, 141-151. [CrossRef] 
43. Hartley, J. Longitudinal studies of the effects of new technologies on writing: Two case studies. Stud. Writ. 2007, 20, 293.

44. Gillam, L. Readability for author profling? Notebook for PAN at CLEF 2013. In Working Notes for Conference and Labs of the Evaluation Forum (CLEF) 2013 Conference, Information Access Evaluation Meets Multilinguality, Multimodality, and Visualization, Valencia, Spain, 23-26 Septembre 2013; Forner, P., Navigli, R., Tufis, D., Ferro, N., Eds.; CLEF: Valencia, Spain, 2013.

45. Buter, R.K.; van Raan, A.F. Non-alphanumeric characters in titles of scientifc publications: An analysis of their occurrence and correlation with citation impact. J. Informetr. 2011, 5, 608-617. [CrossRef]

46. Nair, L.B.; Gibbert, M. What makes a 'good' title and (how) does it matter for citations? A review and general model of article title attributes in management science. Scientometrics 2016, 107, 1331-1359. [CrossRef]

47. Lewison, G.; Hartley, J. What's in a title? Numbers of words and the presence of colons. Scientometrics 2005, 63, 341-356. [CrossRef]

48. Subotic, S.; Mukherjee, B. Short and amusing: The relationship between title characteristics, downloads, and citations in psychology articles. J. Inf. Sci. 2014, 40, 115-124. [CrossRef]

49. Habibzadeh, F.; Yadollahie, M. Are shorter article titles more attractive for citations? Crosssectional study of 22 scientific journals. Croat. Med. J. 2010, 51, 165-170. [CrossRef]

50. Glänzel, W.; Thijs, B. Does co-authorship inflate the share of self-citations? Scientometrics 2004, 61, 395-404. [CrossRef]

51. Franceschet, M.; Costantini, A. The effect of scholar collaboration on impact and quality of academic papers. J. Informetr. 2010, 4, 540-553. [CrossRef]

52. Li, C.; Ji, X.; Luo, X. Phytoremediation of Heavy Metal Pollution: A Bibliometric and Scientometric Analysis from 1989 to 2018. Int. J. Environ. Res. Public Health 2019, 16, 4755. [CrossRef]

53. Dias, L.; Gerlach, M.; Scharloth, J.; Altmann, E.G. Using text analysis to quantify the similarity and evolution of scientifc disciplines. R. Soc. Open Sci. 2018, 5, 171545. [CrossRef] [PubMed]

54. Escorsa, P.; Maspons, R. De la Vigilancia Tecnológica a la Inteligencia Competitiva; Pearson Educación: Madrid, Spain, 2001; pp. 88-90.

55. Garfield, E. Little Science, Big Science and beyond gathers together the major works of Derek de Solla Price. Essays Inf. Sci. 1987, 10, 72.

56. Price, D.S. Little Science, Big Science-And Beyond; Columbia University Press: New York, NY, USA, 1986; pp. 5-29.

57. Spinak, E. Indicadores cienciométricos. Ciência da Inf. 1998, 27, 141-148. [CrossRef]

58. Vega-Muñoz, A.; Salinas-Galindo, C.M. Scientific Production Analysis in Public Affairs of Chile and Peru. Challenges for a Better Public Management. Lex 2017, 15, 463-478.

59. Okumus, F.; Köseoglu, M.A.; Morvillo, A.; Altin, M. Scientific progress on strategic management in hospitality and tourism: A state-of-the-art. Tour. Rev. 2017, 72, 261-273. [CrossRef]

60. Serrano, L.; Sianes, A.; Ariza-Montes, A. Using Bibliometric Methods to Shed Light on the Concept of Sustainable Tourism. Sustainability 2019, 11, 6964. [CrossRef]

61. Carabantes-Alarcón, D.; Alou-Cervera, L. Evaluation of research activity in Microbiology: The role of the Spanish Journal of Chemotherapy. Rev. Esp. Quimioter. 2019, 32, 571-576.

62. Moravcsik, M.J. Applied Scientometrics: An Assessment Methodology for Developing Countries. Scientometrics 1985, 7, 165-176. [CrossRef]

63. Frenken, K.; Hardeman, S.; Hoekman, J. Spatial scientometrics: Towards a cumulative research program. J. Informetr. 2009, 3, 222-232. [CrossRef]

64. Fu, H.-Z.; Chuang, K.-Y.; Wang, M.-H.; Ho, Y.-S. Characteristics of research in China assessed with Essential Science Indicators. Scientometrics 2011, 88, 841-862. [CrossRef]

65. Mikhaylov, A.; Mikhaylova, A.; Hvaley, D. Knowledge Hubs of Russia: Bibliometric Mapping of Research Activity. J. Scientometr. Res. 2020, 9, 1-10. [CrossRef]

66. Zhang, D.; Xu, J.; Zhang, Y.; Wang, J.; He, S.; Zhou, X. Study on sustainable urbanization literature based on Web of Science, scopus, and China national knowledge infrastructure: A scientometric analysis in CiteSpace. J. Clean. Prod. 2020, 264, 121537. [CrossRef]

67. Vega-Muñoz, A.; Arjona-Fuentes, J.M. Social Networks and Graph Theory in the Search for Distant Knowledge in the Field of Industrial Engineering. In Advanced Applications of Graph Theory in Modern Society; Pal, M., Samanta, S., Pal, A., Eds.; IGI-Global: Hershey, PA, USA, 2020; pp. 397-418. 
68. Price, D.S. A general theory of bibliometric and other cumulative advantage processes. J. Assoc. Inf. Sci. 1976, 27, 292-306. [CrossRef]

69. Dobrov, G.M.; Randolph, R.H.; Rauch, W.D. New options for team research via international computer networks. Scientometrics 1979, 1, 387-404. [CrossRef]

70. Ruhanen, L.; Weiler, B.; Moyle, B.D.; McLennan, C.J. Trends and patterns in sustainable tourism research: A 25-year bibliometric analysis. J. Sustain. Tour. 2015, 23, 517-535. [CrossRef]

71. Del Río-Rama, M.; Maldonado-Erazo, C.; Álvarez-García, J. State of the art of research in the sector of thermalism, thalassotherapy and spa: A bibliometric analysis. Eur. J. Tour. Res. 2018, 19, 56-70.

72. Albort-Morant, G.; Henseler, J.; Leal-Millán, A.; Cepeda-Carrión, G. Mapping the Field: A Bibliometric Analysis of Green Innovation. Sustainability 2017, 9, 1011. [CrossRef]

73. Mulet-Forteza, C.; Martorell-Cunill, O.; Merigó, J.M.; Genovart-Balaguer, J.; Mauleon-Mendez, E. Twenty five years of the Journal of Travel \& Tourism Marketing: A bibliometric ranking. J. Travel Tour. Mark. 2018, 35, 1201-1221.

74. Van Eck, N.J.; Waltman, L. Software survey: VOSviewer, a computer program for bibliometric mapping. Scientometrics 2010, 84, 523-538. [CrossRef]

75. Cassettari, R.R.B.; Pinto, A.L.; Rodrigues, R.S.; Santos, L.S. Comparison of Zipf's law in textual content and oral discourse. El Prof. Informac. 2015, 24, 157-167. [CrossRef]

76. Zipf, G.K. Selected Studies of the Principle of Relative Frequency in Language; Harvard University Press: Cambridge, MA, USA, 1932.

77. Bulik, S. Book Use as a Bradford-Zipf Phenomenon. Coll. Res. Libr. 1978, 39, 215-219. [CrossRef]

78. Morse, P.M.; Leimkuhler, F.F. Technical Note-Exact Solution for the Bradford Distribution and Its Use in Modeling Informational Data. Oper. Res. 1979, 27, 187-198. [CrossRef]

79. Pontigo, J.; Lancaster, F.W. Qualitative aspects of the Bradford distribution. Scientometrics 1986, 9, 59-70. [CrossRef]

80. Kumar, S. Application of Bradford's Law to Human-Computer Interaction Research Literature. DESIDOC J. Lib. Inf. Technol. 2014, 34, 223-231.

81. Shelton, R.D. Scientometric laws connecting publication counts to national research funding. Scientometrics 2020, 123, 181-206. [CrossRef]

82. Lotka, A.J. The frequency distribution of scientific productivity. J. Wash. Acad. Sci. 1926, 16, 317-323.

83. Andrade-Valbuena, N.A.; Merigo-Lindahl, J.M.; Olavarrieta-Soto, S. Bibliometric analysis of entrepreneurial orientation. World J. Entrep. Manag. Sustain. Dev. 2019, 15, 45-69. [CrossRef]

84. Durán-Sánchez, A.; Álvarez-García, J.; del Río-Rama, M.d.l.C. Nature sports: State of the art of research. Ann. Leis. Res. 2020, 23, 52-78. [CrossRef]

85. Marzi, G.; Caputo, A.; Garces, E.; Dabic, M. A Three Decade Mixed-Method Bibliometric Investigation of the IEEE Transactions on Engineering Management. IEEE Trans. Eng. Manag. 2020, 67, 4-17. [CrossRef]

86. Kullenberg, C.; Kasperowski, D. What Is Citizen Science?-A Scientometric Meta-Analysis. PLoS ONE 2016, 11, e0147152. [CrossRef]

87. Köseoglu, M.A.; Okumus, F.; Putra, E.D.; Yildiz, M.; Dogan, I.C. Authorship Trends, Collaboration Patterns, and Co-Authorship Networks in Lodging Studies (1990-2016). J. Hosp. Mark. Manag. 2018, 27, 561-582. [CrossRef]

88. Lojo, A.; Li, M.; Cànoves, G. Co-authorship Networks and Thematic Development in Chinese Outbound Tourism Research. J. Chin. Tour. Res. 2019, 15, 295-319. [CrossRef]

89. Köseoglu, M.A.; Sehitoglu, Y.; Craft, J. Academic foundations of hospitality management research with anemerging country focus: A citation and co-citation analysis. Int. J. Hosp. Manag. 2015, 45, 130-144. [CrossRef]

90. González-Serrano, M.H.; Jones, P.; Llanos-Contreras, O. An overview of sport entrepreneurship field: A bibliometric analysis of the articles published in the Web of Science. Sport Soc. 2020, 23, 296-314. [CrossRef]

91. Clarivate Web of Science. Available online: http://webofknowledge.com/wos (accessed on 13 August 2020).

92. Red Interuniversitaria de Posgrados en Turismo de Posgrados en Turismo. Available online: https://red-intur. org/participantes.html (accessed on 8 August 2020).

93. Garín, A.; Quinteros, B. Caracterización de los emprendedores y su percepción sobre el turismo rural: Curarrehue, Chile. Pasos 2020, 18, 219-234. [CrossRef] 
94. Padilla, P.; Sanchez, S.; Hernandez, J.; Mendoza, Y. Management of research data at the Regional Tourism Observatories in Chile. Cuad. Tur. 2020, 571-573. [CrossRef]

95. Mondaca-Marino, C.; Arriagada-Milaman, A.; Montecinos-Astorga, A.; Colther-Marino, C. Modelamiento y pronóstico de la demanda turística a nivel regional en chile: Un análisis con modelos SARIMA. Turismo 2020, 9, 1-12.

96. Baez-Montenegro, A.; Devesa, M. Understanding the determinants of festival attendee spending: The role of cultural capital. Int. J. Event Festiv. Manag. 2020, 11, 145-159. [CrossRef]

97. Aguirre, D. Conceptual implications of Peru's recent charm offensive in Chile: Societal-level engagement driving a shift in bilateral relations? Place Brand. Public Dipl. 2020, 16, 121-130. [CrossRef]

98. Merigo, J.M.; Mulet-Forteza, C.; Martorell, O.; Merigo-Lindahl, C. Scientific research in the tourism, leisure and hospitality field: A bibliometric analysis. Anatolia 2020, 31, 494-508. [CrossRef]

99. Apaolaza, V.; Hartmann, P.; Fernández-Robin, C.; Yáñez, D. Natural plants in hospitality servicescapes: The role of perceived aesthetic value. Int. J. Contemp. Hosp. Manag. 2020, 32, 665-682. [CrossRef]

100. Radic, A.; Arjona-Fuentes, J.M.; Ariza-Montes, A.; Han, H.; Law, R. Job demands-job resources (JD-R) model, work engagement, and well-being of cruise ship employees. Int. J. Hosp. Manag. 2020, 88, 102518. [CrossRef]

101. Ball, P. Masa Crítica. Cambio, Caos y Complejidad; Fondo de Cultura Económica/Turner: Mexico City, Mexico, 2010; pp. 437-471.

102. Martorell-Cunill, O.; Socias-Salvá, A.; Gonzalez, L.O.; Mulet-Forteza, C. Thirty-fifth anniversary of the International Journal of Hospitality Management: A bibliometric overview. Int. J. Hosp. Manag. 2019, 78, 89-101. [CrossRef]

103. Figueroa-Domecq, C.; Pritchard, A.; Segovia-Pérez, M.; Morgan, N.; Villacé-Molinero, T. Tourism gender research: A critical accounting. Ann. Tour. Res. 2015, 52, 87-103. [CrossRef]

104. Nunkoo, R.; Thelwall, M.; Ladsawut, J.; Goolaup, S. Three decades of tourism scholarship: Gender, collaboration and research methods. Tour. Manag. 2020, 78, 104056. [CrossRef]

105. Sodré, M. A Post-Disciplinary Science. In The Science of the Commons; Palgrave Macmillan-Cham: New York, NY, USA, 2019; pp. 9-33.

106. Fernandes, E.; Pacheco, R.R.; Fernandes, V.A. Tourism openness, trade openness, and currency-purchasing power in Brazil: A causality analysis. Int. J. Tour. Res. 2019, 21, 197-205. [CrossRef]

107. Figueroa-Sterquel, R.; Chia, E.; Yanca, L.T.; Triviño, J.A. Efectos de la certificación turística en la gobernanza territorial: El caso del Sello "Biosfera”, Olmué (Chile). Pasos 2016, 14, 675-690. [CrossRef]

108. García-Alvarado, R.; Kelly, M.T.; Fernández, H.A. Visitando los bosques del sur: Imágenes arquitectónicas y desafíos locales en Huilo Huilo, Chile. Rosa Dos Ventos 2017, 9, 338-355.

109. Pablo-Romero, M.D.P.; Sánchez-Braza, A.; Sánchez-Rivas, J. Tourism and electricity consumption in 9 European countries: A decomposition analysis approach. Curr. Issues Tour. 2019. [CrossRef]

110. Arjona-Fuentes, J.M.; Ariza-Montes, A.; Han, H.; Law, R. Silent threat of presenteeism in the hospitality industry: Examining individual, organisational and physical/mental health factors. Int. J. Hosp. Manag. 2019, 82, 191-198. [CrossRef]

111. Gómez, M.; Imhoff, B.; Martín-Consuegra, D.; Molina, A.; Santos-Vijande, M.L. Language tourism: The drivers that determine destination choice intention among US students. Tour. Manag. Perspect. 2018, 27, 125-135. [CrossRef]

112. Artigas, E.M.; Yrigoyen, C.C.; Moraga, E.T.; Villalón, C.B. Determinants of trust towards tourist destinations. J. Destin. Mark. Manag. 2017, 6, 327-334.

113. Amador, L.; Campoy-Muñoz, P.; Cardenete, M.A.; Delgado, M.C. Economic impact assessment of small-scale sporting events using Social Accounting Matrices: An application to the Spanish Football League. J. Policy Res. Tour. Leis. Events 2017, 9, 230-246. [CrossRef]

114. Gómez-Aguilar, A.; Yagüe-Guillén, M.J.; Villaseñor-Román, N. Destination Brand Personality: An Application to Spanish Tourism. Int. J. Tour. Res. 2016, 18, 210-219. [CrossRef]

115. Brida, J.G.; Bukstein, D.; Garrido, N.; Tealde, E. Cruise passengers' expenditure in the Caribbean port of call of Cartagena de Indias: A cross-section data analysis. Tour. Econ. 2012, 18, 431-447. [CrossRef]

(C) 2020 by the authors. Licensee MDPI, Basel, Switzerland. This article is an open access article distributed under the terms and conditions of the Creative Commons Attribution (CC BY) license (http://creativecommons.org/licenses/by/4.0/). 